\title{
Fascitis nodular en el territorio maxilofacial. Presentación de dos casos y revisión de la literatura
}

\author{
Nodular fascitis of the maxillofacial region. \\ Two case reports and a review of the literature
}

\author{
F. Almeida' , M. Picón², M. Pezzi', E. Sánchez-Jaúregui', R. Carrillo³, J.L. Martínez-Lage
}

Resumen: La fascitis nodular es una entidad clínica relativamente poco frecuente caracterizada por una tumoración de crecimiento rápido, aunque de comportamiento clínico benigno y de características histológicas pseudosarcomatosas. Su aparición en el territorio maxilofacial es poco común, por lo que presentamos dos casos que acudieron por nódulos de consistencia dura, indoloros, en las regiones cigomática y paramandibular, que fueron diagnosticados de fascitis nodular. Destacamos estos casos por tratarse de fascitis nodular de localización atípica y revisamos su histopatología.

Palabras clave: Fascitis nodular; Fibromatosis pseudosarcomatosa; Fascitis infiltrativa.

Recibido: 24.10 .05

Aceptado: 06.10 .06

\begin{abstract}
Nodular fasciitis is a relatively rare clinical entity that is characterized by a rapidly growing tumor-like mass, although it has a benign clinical behavior and pseudosarcomatous histological characteristics. Its appearance in the maxillofacial area is unusual, and two cases are presented of patients that attended as a result of nodules that were hard in consistency, non-tender, in the zygomatic region beside the mandible, and that were diagnosed as nodular fasciitis. The cases are highlighted because of the atypical location of the nodular fasciitis and the histopathology is revised.
\end{abstract}

Key words: Nodular fasciitis; Pseudosarcomatous fibromatosis; Infiltrative fasciitis.

1 Médico Residente.

2 Médico Adjunto.

4 Jefe de Servicio.

Servicio de Cirugía Oral y Maxilofacial.

3 Médico Adjunto.

Servicio de Anatomía Patológica.

Hospital Universitario Ramón y Cajal. Madrid, España

Correspondencia:

Fernando Almeida Parra

C/ Cardenal Marcelo Spinola $48,17^{\circ} \mathrm{C}$

28016 Madrid, España

E-mail: falmeida.hrc@salud.madrid.org 


\section{Introducción}

La fascitis nodular, descrita originalmente por Konwaler y cols., en 1955 bajo el término de fibromatosis (fascitis) pseudosarcomatosa subcutánea, 1 es una entidad clínica no muy frecuente que, a pesar de sus características histológicas pseudosarcomatosas, tiene un comportamiento clínico benigno. En 1966 Mehrengan y cols., describieron 17 casos con sus características epidemiológicas, clínicas e histopatológicas proponiendo el término de fascitis nodular por ser más breve y descriptivo. ${ }^{2}$ Aunque es una lesión mesenquimal frecuente en las partes blandas de otras localizaciones, especialmente la extremidad superior y el tronco, su aparición en cabeza y cuello no es tan común, ${ }^{3}$ por lo que puede ser poco conocida por los cirujanos orales y maxilofaciales.

Presentamos dos casos de fascitis nodular vistos en el Servicio de Cirugía Oral y Maxilofacial del Hospital Ramón y Cajal (Madrid) que asientan en el tejido subcutáneo de la región cigomática y paramandibular.

\section{Casos clínicos}

\section{Caso 1}

Se trata de una mujer de 39 años, no fumadora, sin alergias medicamentosas conocidas ni antecedentes médico-quirúrgicos de interés, que acudió a Consultas Externas por presentar una tumoración de crecimiento progresivo en región cigomática derecha de dos meses de evolución, indolora. A la exploración clínica se palpaba un nódulo de aproximadamente $1,5 \mathrm{~cm}$ de diámetro mayor, de consistencia dura, indoloro, que afectaba al tejido celular subcutáneo, no adherido al hueso malar. No se palpaban adenopatías cervicales. Se realizó RM facial que fue informada como pequeño nódulo sólido isointenso en secuencias pT1 y pT2 con realce tras el contraste, de localización superficial en la región malar derecha (Fig. 1). En la secuencia en supresión grasa se excluyó lipoma. Fue informado como tumor de partes blandas (fibroma, leiomioma, sarcoma, etc.) de unos $13 \mathrm{~mm}$ de diámetro, por lo que se decidió realizar PAAF con el resultado de lesión proliferativa mesenquimal, sugestiva de fascitis nodular.

Se realizó la extirpación quirúrgica del nódulo por vía intraoral. El estudio histológico del nódulo extirpado demostró una proliferación moderadamente densa de células fusiformes, distribuidas en haces desordenados o en forma "de pluma", con núcleos vesiculosos, grandes y moderada actividad mitótica. Entre las células se observaba una matriz colágena laxa o mixoide, algunas célu-

\section{Introduction}

Nodular fasciitis was described originally by Konwaler and cols in 1955 under term subcutaneous pseudosarcomatous fibromatosis (fasciitis). ${ }^{1}$ It is a clinical entity that is not very common, in spite of its pseudosarcomatous histological characteristics, with behavior that is clinically benign. In 1966 Mehrengan and cols described 17 cases with epidemiological, clinical and histopathological characteristics, and they proposed the term nodular fasciitis because it was briefer and more descriptive. ${ }^{2}$ Although it is a mesenchymal lesion commonly found in soft tissue in other locations, especially in the upper limbs and trunk, its appearance in the head and neck is not very common, ${ }^{3}$ and the oral and maxillofacial surgeon may not be very familiar with it.

Two cases are presented of nodular fasciitis that were seen by the Service of Oral and Maxillofacial Surgery of the Hospital Ramón y Cajal (Madrid) that arose in the subcutaneous tissue in the zygomatic region beside the mandible.

\section{Case reports}

\section{Case 1}

The patient was a 39-year-old female, non-smoker, with no known medical allergies and with no medical-surgical history of interest. She attended the outpatient unit because of a non-tender, tumor-like mass that had been growing rapidly in the right zygomatic area over the previous two months. The clinical examination showed a nodule that measured approximately $1.5 \mathrm{~cm}$ in greatest diameter, that was hard in consistency, non-tender and that affected the subcutaneous cell tissue. It was not adhered to the malar bone. No adenopathy in the neck was noted. MRI of the face was carried out, and a small solid nodule was reported that was isointense on $\mathrm{T} 1$ and $\mathrm{T} 2$ after contrast enhancement. It had a superficial location in the region of the right malar (Fig. 1). Following the fat suppression sequence, lipoma was excluded. The report was of a soft tissue tumor (fibroma, leiomyoma, sarcoma, etc.) with a $13 \mathrm{~mm}$ diameter, and FNA was carried out, which gave the result of mesenchymal prolifer- 
las inflamatorias y hematíes extravasados (Fig. 2). Los bordes de la lesión eran marcadamente irregulares. El diagnóstico anatomopatológico fue de fascitis nodular. La paciente se encuentra asintomática en la actualidad tras un seguimiento de 24 meses.

\section{Caso 2}

Mujer de 21 años, no fumadora, sin antecedentes médico-quirúrgicos de interés ni alergias medicamentosas conocidas, que presentaba una tumoración subcutánea, adherida a piel, en margen derecho facial en proximidad a pliegue mentogeniano con invaginación cutánea central de tres meses de evolución, de crecimiento progresivo (Fig. 3). No refería antecedentes traumáticos en la zona descrita. A la exploración se palpaba nódulo de aproximadamente $2 \mathrm{~cm}$ de diámetro mayor, de consistencia dura, ligeramente doloroso, adherido a piel, que afectaba al tejido celular subcutáneo, sin involucrar al hueso mandibular. La TC evidenciaba lesión nodular localizada en el tejido celular subcutáneo de la región mandibular derecha, de $2 \mathrm{~cm}$ de diámetro, sin erosión ósea ni extensión a planos adyacentes. Se realizó PAAF del nódulo con el resultado de lesión proliferativa mesenquimal, sugestiva de proceso reactivo tipo fascitis nodular.

Con el diagnóstico de presunción de fascitis nodular se realizó la extirpación quirúrgica del nódulo por vía extraoral. El estudio histológico de la lesión extirpada demostró una proliferación fusocelular de aspecto reactivo, muy similar a la observada en el caso 1. La lesión se diagnosticó igualmente como fascitis nodular. La paciente se encuentra asintomática en la actualidad tras un seguimiento de 14 meses.

\section{Discusión}

Las proliferaciones fibroblásticas benignas constituyen un grupo heterogéneo de entidades bien definidas que son reactivas más que verdaderas neoplasias. Entre estas entidades se encuentran la fascitis nodular, la fascitis proliferativa y la miositis proliferativa, todas ellas de crecimiento rápido y de gran celularidad. ${ }^{4}$

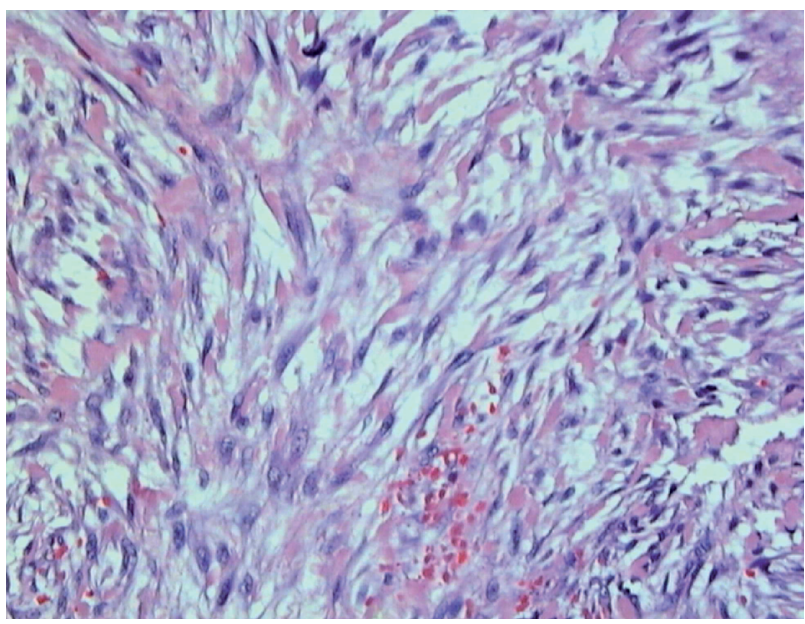

Figura 2. Aspecto histológico de la lesión. Fibroblastos dispuestos en forma "de pluma" con abundante matriz mixoide alrededor. Los núcleos celulares son grandes y vesiculosos. Se observan hematíes extravasados.

Figure 2. Histological appearance of the lesion. Fibroblasts are shown arranged in a feather shape surrounded by abundant myxoid matrix. The nuclei of the cells are large and vesicular. Extravasated red blood cells can be observed.

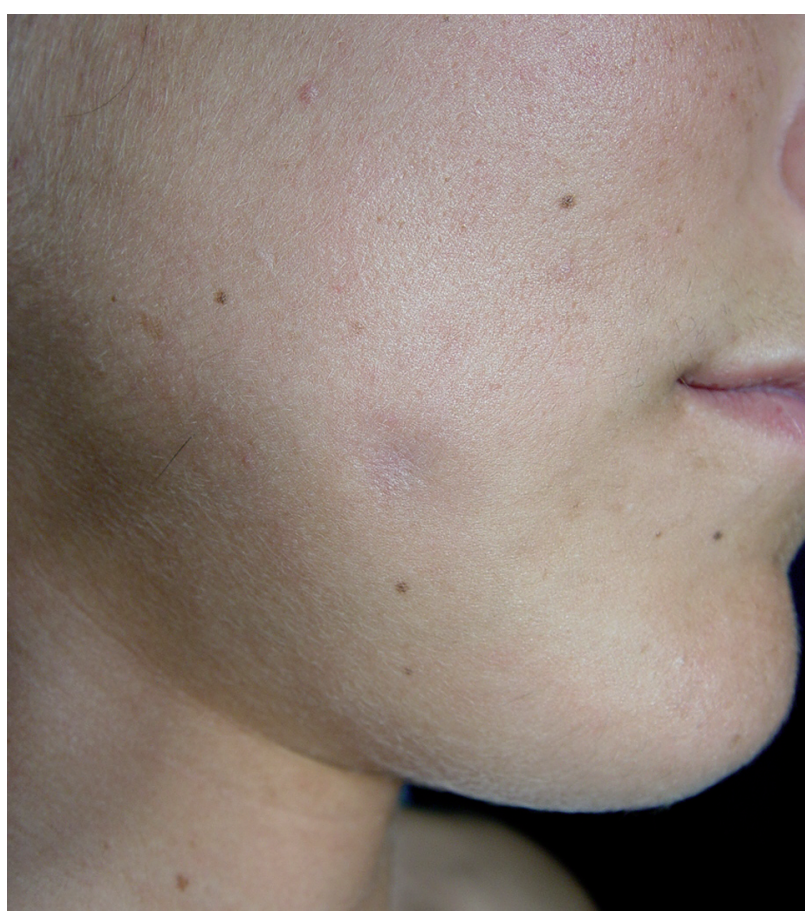

Figura 3. Aspecto clínico. Presenta tumoración subcutánea, adherida a piel, en margen derecho facial en proximidad a pliegue mentogeniano con invaginación cutánea central.

Figure 3. Clinical appearance. Subcutaneous tumor-like mass is shown that is adhered to the skin, on the right edge of her face by the mental crease with central cutaneous invagination. ative lesion, that was suggestive of nodular fasciitis. Surgical excision of the nodule was carried out intraorally. The histological study of the extracted nodule revealed a proliferation of spindle-shaped cells that was moderately dense, and distributed in haphazardly arranged bundles in a "feather shape". There were large vesicular nuclei and moderate mitotic activity. Between the cells a loose or myxoid collagenous matrix could be observed with some inflammatory cells and extravasated red blood cells (Fig. 2). The borders of the lesion were distinctly irregular. The anatomopathological diagnosis was of nodular fasciitis. The patient is currently asymptomatic after a follow-up of 24 months.

\section{Case 2}

The patient was a 21-yearold female, non-smoker, with no medical-surgical history of interest, and no known drug allergy. She presented with a subcutaneous tumorlike mass that was attached to the skin, on the right edge of the face by the mental crease with central cutaneous invagination. It had been evolving for three months and it was growing progressively (Fig. 3). There was no history of trauma in the area. On examination a nodule could be felt with a maximum diameter of $2 \mathrm{~cm}$. It was hard in consistency, slightly painful, and it was attached to the skin. It was affecting subcutaneous cellular tissue and there was no involvement of the mandibular bone. The CAT scan showed a nodular lesion that was located in the subcutaneous tissue in the right mandibular region, which had a diameter of $2 \mathrm{~cm}$ There was no bone 
A lo largo de la historia se ha denominado la fascitis nodular de diferentes maneras, tales como fascitis infiltrativa, fascitis pseudosarcomatosa y fibromatosis subcutánea pseudosarcomatosa. Se trata de una lesión relativamente poco frecuente descrita en pacientes de todas las edades, aunque la incidencia es más alta entre la tercera y quinta décadas de la vida. No se aprecian diferencias significativas en la prevalencia entre hombres y mujeres. Puede aparecer en todas las localizaciones del organismo excepto en las vísceras, aunque la localización más frecuente es en las extremidades superiores y el tronco. En un 7-20\% de los casos se localiza en territorio maxilofacial, sobre todo a nivel del tejido subcutáneo de la región malar y/o mandibular, como en los casos que presentamos. Las lesiones intraorales son excepcionales. ${ }^{5}$

Es una lesión proliferativa benigna de miofibroblastos que habitualmente aparece en el tejido subcutáneo o entre las fascias musculares, aunque en raras ocasiones asienta en el espesor del tejido muscular. Su etiología es desconocida, pero se piensa que los traumatismos repetidos sobre la zona afectada pudieran influir en su patogénesis, pues habitualmente asienta en zonas prominentes como el ángulo y cuerpo mandibular y el cigoma. ${ }^{6}$ Se han descrito casos autolimitados, con remisión espontánea del nódulo, lo que apoyaría esta hipótesis patogénica. Se presenta como una tumoración de crecimiento rápido en la dermis o en la submucosa. La lesión es dura y bien circunscrita, aunque no encapsulada y generalmente indolora.

El comportamiento clínico en el área de cabeza y cuello es similar al de otras localizaciones y se caracteriza por el rápido crecimiento de la tumoración de semanas de evolución, aunque Price y cols., afirman que en la mayoría de los casos el crecimiento es lento e incluso nulo.7, 8 En nuestros casos en uno de ellos el crecimiento fue rápido (caso $n^{\circ} 2$ ) mientras que en el otro fue lento o nulo. Las lesiones son nodulares, duras e indoloras.

Desde el punto de vista histológico la fascitis nodular se considera una proliferación reactiva, más que tumoral, de células con diferenciación miofibroblástica. ${ }^{9}$ En las primeras descripciones se destacó su parecido histológico con sarcomas de partes blandas, de ahí las denominaciones que incluían el término "pseudosarcomatosa". Con el tiempo se ha llegado a una buena caracterización de la lesión y su diagnóstico histológico no suele plantear problemas al patólogo experimentado. La presencia de células fusiformes grandes pero sin un verdadero pleomorfismo y atipia nuclear es muy constante. Además esta celularidad se dispone en haces laxos, desorganizados, en forma que se ha denominado "en pluma", con un aspecto que recuerda a los cultivos celulares. Las mitosis pueden ser abundantes pero no aparecen figuras atípicas. También son muy característicos los focos de infiltrado inflamatorio y de hematíes extravasados. Sólo en caso de recibir muestras pequeñas, incompletas o artefactadas se pueden generar problemas de diagnóstico histológico. La correlación clínico-patológica es en estos casos muy importante. La localización superficial, en tejido subcutáneo o fascia, el pequeño tamaño, el crecimiento rápido son todos detalles muy característicos.

El tratamiento de elección lo constituye le resección quirúrgi$\mathrm{ca}$, con buenos resultados incluso en casos en los que la extirpación fue incompleta. ${ }^{10}$ Se ha propuesto el tratamiento con inyec- erosion, nor was there extension to adjacent layers. FNA was carried out of the nodule and a mesenchymal proliferative lesion was reported, suggestive of a reactive process of a nodular fasciitis type.

With the presumed diagnosis of nodular fasciitis, extraoral surgical excision was carried out of the node. The histological study of the excised lesion showed a proliferation of spindle-shaped cells that appeared to be reactive, very similar to those observed in Case 1. The lesion was also diagnosed as nodular fasciitis. The patient is currently asymptomatic after a follow-up of 14 months.

\section{Discussion}

Benign fibroblastic proliferation represents a group of heterogeneous entities that are well-defined, and that are reactive rather than true neoplasms. Nodular fasciitis is found among theses entities together with proliferative fasciitis and proliferative myositis. All have rapid growth and rich cellularity. ${ }^{4}$

Nodular fasciitis has throughout history been given different names, such as infiltrative fasciitis, pseudosarcomatous fasciitis and pseudosarcomatous subcutaneous fibromatosis. It is a lesion that affects patients of all ages that is very rarely described, although the incidence rate is higher in the third and fifth decades in life. Significant differences in male and female prevalence have not been appreciated. It can appear in all areas of the body except the viscera, although the most common location is in the upper limbs and torso. $7-20 \%$ of cases are located in the maxillofacial area, especially in the subcutaneous tissue of the malar and/or mandibular region, as in the cases presented. Intraoral lesions are exceptional. ${ }^{5}$

It is a benign proliferative lesion of myofibroblasts that commonly appears in subcutaneous tissue or between muscle fasciae, although on rare occasions it will arise within the muscle tissue thickness. Its etiology is unknown, but it is thought that repeated trauma to the affected area could influence its pathogenesis, as it commonly arises in prominent areas such as the mandibular angle and body, and the zygoma. ${ }^{6}$ Selflimiting cases have been described with spontaneous remission of the nodule, which would support this pathogenic hypothesis. It appears as a rapidly growing lesion of the dermis or submucosa. The lesion is hard and well-circumscribed, although not encapsulated, and it is generally non-tender.

Clinical behavior in the area of the head and neck is similar to that in other locations and it is characterized by rapid growth of the mass over weeks, although Price and cols. affirm that in most cases the nodule grows slowly or even not at all.7, 8 In our cases one of them had rapid growth (Case 2) while in the other growth was slow or not at all. The lesions were nodular, hard and non-tender.

From the histological point of view, nodular fasciitis is considered a reactive proliferation, more than tumoral, of 
ción de corticoides intralesionales, pero se debe reservar a casos muy concretos. ${ }^{11} \mathrm{Si}$ la lesión recidiva se debe sospechar una resección incompleta, o bien habría que revisar el diagnóstico original. ${ }^{10}$

\section{Bibliografía}

1. Konwaler BE, Keasbey L, Kaplan L. Subcutaneous pseudosarcomatous fibromatosis (fascitis). Am J Clin Pathol 1955;25:241-52.

2. Mehregan AH. Nodular fascitis. Arch Dermatol 1966;93:204-210.

3. Bernstein KE, Lattes R. Nodular (pseudosarcomatous) fascitis, a non-recurrent lesion. Clinicopathological study of 134 cases. Cancer 1982;49:1668-78.

4. Mauleón C, Chavarría E, Suárez R et al. Fascitis Nodular. Actas Dermosifiliogr 2003;94:90-2.

5. Martínez-Blanco M, Bagán JV, Alba JR, Basterra J. Maxillofacial nodular fascitis: a report of 3 cases. J Oral Maxillofac Surg 2002;60:1211-4.

6. DiNardo LJ, Wetmore RF, Potsic WP. Nodular fasciitis of the head and neck in children. A deceptive lesion. Arch Otolaryngol Head Neck Surg 1991;117:10012.

7. Price EB, Silliphant WM, Shuman R. Nodular fasciitis: a clinicopathologic analysis of 65 cases. Am J Clin Pathol 1961;35:122-36.

8. Nair P, Barrett AW, Theodossy T. Oral nodular fascitis: case report. Br J Oral MaxiIlofac Surg 2004; 42: 360-2.

9. Dayan D, Nasrayah V, Vered M. Clinico-pathologic correlations of myofibroblastic tumors of the oral cavity: 1. Nodular fasciitis. J Oral Pathol Med 2005; 34: 426-35. Review.

10. Silva P, Bruce IA, Malik T, Homer J, Banerjee S. Nodular fasciitis of the head and neck. J Laryngol Otol 2005;119:8-11.

11. Grabam B, Barret T, Goltz R. Nodular fascitis: responde to intralesional corticoesteroids. J Am Acad Dermatol 1999;40:490-92. cells with myofibroblastic differentiation. ${ }^{9}$ When it was first described, its histological similarity with the soft tissue sarcoma was highlighted, leading to terms for it that included "pseudosarcomatous". Over time, the lesion has become well-characterized and its histological diagnosis does not tend to give the experienced pathologist any problems. The presence of large spindle-shaped cells, but without any true pleomorphism and nuclear atypia is very constant. In addition this cellularity is arranged in loose bundles, haphazardly arranged, in a so-called "feather" shape that is reminiscent of cell culture. There may be abundant mitoses but no atypical figures are shown. Foci of inflammatory infiltrate and extravasated red blood cells are also very characteristic. Only if small, incomplete samples are received, or samples with artifacts, will problems arise in its histologic diagnosis. The clinico-pathologic correlation is, in these cases, very important. Its superficial location in subcutaneous tissue or fascia, its small size and rapid growth are all very characteristic details.

Surgical resection is the treatment of choice. Good results are obtained even in cases where the excision is incomplete..$^{10}$ Intralesional corticoid therapy with injections has been proposed, but this should be reserved for very specific cases. ${ }^{11}$ If there is recurrence, incomplete resection should be suspected, or the original diagnosis should be revised. ${ }^{10}$ 